\title{
Arte e movimento estudantil: análise de uma obra de Antonio Manuel ${ }^{1}$
}

Artur Freitas ${ }^{2}$

UFPR

\section{RESUMO}

Podem as manifestações visuais, e no limite a própria visualidade, participar crítica e reflexivamente dos grandes debates do espaço público? Em linhas gerais, é justamente a crença nesse poder de intervenção crítica que manteve acesa, no caso das artes plásticas, uma intensa atividade pública, contestatória e coletiva das vanguardas brasileiras durante o regime militar, sobretudo em seus primeiros anos de vigência. E é a partir desse contexto histórico que este artigo pretende analisar algumas implicações estéticas e ideológicas presentes na obra Movimento estudantil 68, serigrafia de Antonio Manuel premiada no Salão Paranaense de 1968. Produzida em plena efervescência política do movimento estudantil, mas exibida ao público nos primeiros dias de vigência do Ato Institucional $\mathrm{n}^{\mathrm{O}} 5$, Movimento estudantil 68 será aqui entendida como uma trama discursiva em que se cruzam história e visualidade.

Palavras-chave: Arte e política; Arte brasileira; Antonio Manuel.

\begin{abstract}
Can the visual manifestations participate critic and reflexively of the great debates of the public space? Usually, during the first years of military regime, the plastic arts believed in this participation, and this faith sustained the public, oppositional and collective activity of the Brazilian vanguards. In this historical context, therefore, this article will analyze some aesthetic and ideological implications presents in the work Movimento estudantil 68, engraving of Antonio Manuel rewarded in the Salão Paranaense of 1968. Movimento estudantil 68 was produced in the political effervescence peak of student movement, but it was exhibited for the public in the first days of Act Institutional number 5. Thus, this art work will be understood here as a discursive plot, a crossing between history and visuality.
\end{abstract}

Keywords: Art and Politics; Brazilian Art; Antonio Manuel. 


\section{INTRODUÇÃO}

As manifestações visuais, à sua maneira, têm sempre algo a nos "dizer", algo que, de outra forma, não seria de nenhum modo "dito" - e permaneceria, portanto, para sempre calado, inefável. O conhecimento historiográfico, assim, simplesmente não pode desprezar a contribuição das visualidades para a construção do saber histórico. E é sob essa perspectiva que afirmo - para trabalhar com exemplos — que a história das artes plásticas, e sobretudo das vanguardas, no Brasil, entre o golpe de 1964 e o Ato Institucional no 5, de 1968, consiste num capítulo importante da história cultural brasileira. A relação entre contestação política e experimentalismo poético — dado comum ao teatro, ao cinema e à MPB da época - tem no campo da produção artística brasileira desse período uma arena privilegiada. A necessidade de expandir as possibilidades expressivas no campo das artes plásticas, através da dissolução dos conceitos tradicionais de escultura e pintura e da proposição de uma arte voltada à cultura de massa, à poética do objeto, dos múltiplos, dos ambientais e dos happenings, segue pari passu à necessidade de fazer do meio artístico um espaço vivo de opinião pública. Curiosamente há, nesse período, e como é bem sabido, uma relativa liberdade de expressão ideológica de esquerda entre 1964 e 1968; e as vanguardas brasileiras — das contravenções do grupo Rex, em São Paulo, ao ativo experimentalismo crítico da vanguarda carioca - não deixarão de ter parte ativa nesse processo. Contudo, com o Ato Institucional $\mathrm{n}^{\mathrm{o}} 5$ (o AI-5), o panorama político-cultural do país se altera consideravelmente. A repressão torna-se a nota dominante do regime, e a censura - ou a auto-censura - estende seus braços sobre a produção cultural. $\mathrm{O}$ ambiente é outro, com um horizonte de clara opressão ideológica, e aos críticos da ditadura cabe o silêncio, a metáfora ou a guerrilha.

Tendo em vista essa conjuntura mais ampla, este artigo analisa uma serigrafia intitulada Movimento estudantil 68 - uma obra do artista Antonio Manuel que foi premiada no Salão Paranaense de 1968. Ao partir de um acontecimento muito simples, portanto, em que um artista da vanguarda brasileira envia uma obra contestatória a um salão de arte, a análise da obra seguirá aqui por caminhos diversos de interpretação, procurando levar em conta que mesmo coisas aparentemente pouco significativas podem ajudar na hermenêutica de um acontecimento histórico. Do conturbado contexto dos movimentos estudantis à natureza do prêmio oferecido à obra, da técnica serigráfica bastante peculiar ao envio da obra a um salão de arte, e mesmo do silêncio na mídia à análise das imagens, cada ponto da interpretação das manifestações visuais se volta à história. E vice-versa. 


\section{DA CONVULSÃO AO SILÊNCIO: 1968 E UM SALÃO DE ARTE}

Ao longo de pouco mais de um mês de exposição, 925 pessoas se deram ao trabalho de assinar o livro de visitas do Salão Paranaense de 1968 — um dos principais salões anuais de artes plásticas do país e que, naquele ano, como aliás desde 1954, ocorria na Biblioteca Pública do Paraná, em Curitiba. O número de pessoas que registraram sua presença no Salão de 1968 era o maior dos últimos dez anos, a contar do tempo em que, em meados da década de 1950, o evento chegava a ultrapassar a marca de 1.500, 1.700 assinaturas por tempo de exposição. ${ }^{3}$

Apesar disso o Salão Paranaense de 1968 foi, digamos, "silencioso". Quase nada se comentou sobre ele. Nada de anormal, nenhum debate nos jornais sobre as decisões do júri, nenhuma exclamação elogiosa, tampouco qualquer detração pública, como já ocorrera tantas vezes. Se houve divergências ou polêmicas, largaram-se, por certo, ao plano privado, ou no máximo a algum plano sem registros como as conversas de bar ou as salas de aula. Nada relevante a não ser o silêncio, o que por si só, já nos diz muito. Quando, na data comemorativa de emancipação política do Estado do Paraná, dia 19 de dezembro, o Salão abriu suas portas em sua 25a edição, o país sofria já por seis dias, ainda atônito, os efeitos do AI-5 - conhecido mecanismo político de institucionalização definitiva da repressão no regime militar brasileiro.

Já na noite do dia 12, uma quinta-feira, diversas redações de jornal, rádio e televisão do país foram invadidas por censores e soldados do exército. ${ }^{4}$ O controle da opinião pública era peça fundamental da ação militar naquele momento. Não certamente pela necessidade de qualquer tipo de aliciamento das massas, pois estratégias populistas como essa não ocupavam espaço no repertório político de um governo que parecia não precisar da aprovação popular para poder governar, mas simplesmente pela maximização da capacidade repressora naquele momento estratégico, de "golpe dentro do golpe", como se convencionou dizer. A partir de então o arbítrio e a violência se institucionalizavam enquanto práticas constantes, quase rotineiras, especialmente nas prisões militares, onde a tortura transformava-se de ato de exceção a "método" de coerção. No dia 13, o fatídico, agentes do governo põem em ação a "operação de caça às bruxas", em que a prisão de figuras públicas como o ex-presidente Juscelino Kubitschek já dava mostras "de que ninguém estaria a salvo da caçada". ${ }^{5}$ No plano político o Ato dava plenos poderes ao Executivo, viabilizava o fechamento do Congresso, permitia a intervenção nos Estados e Municípios, admitia a suspensão dos direitos políticos de qualquer cidadão, legitimava a cassação de mandatos e suspendia, inumanamente, o habeas corpus: era o enrijecimento definitivo dos contornos repressivos do re- 
gime militar. A censura imposta à grande imprensa e o controle sobre a circulação de idéias e notícias convertia uma via potencial de esclarecimento e informação numa via de frouxidão e languidez da opinião pública. O momento era de apreensão, de falta de notícias e de incertezas. O tempo estava, realmente, propenso ao silêncio.

Entretanto, o ano de 1968, encerrado naquele 13 de dezembro, não foi, como se sabe, um ano silencioso. A juventude de classe média e universitária, sobretudo em sua fração mais politizada e militante, chegou a incomodar o regime. Enquanto consumidores potenciais esses jovens conseguiam, já há um certo tempo, manter viva a chama de um mercado cultural de protesto em que Caetano Veloso, Chico Buarque, Gilberto Gil e Geraldo Vandré despontavam como ídolos. Os festivais de música, que deviam parte de seu sucesso à televisão, eram, sob esse ângulo, arena privilegiada e fundamental. Em meios mais restritos como o teatro e o cinema de vanguarda despontavam figuras combativas e contraditórias como Zé Celso (Roda viva) e Glauber Rocha (Terra em transe), cujo consumo fechava-se em circuitos menos abrangentes. Surge o Tropicalismo como crise das manobras tradicionais de engajamento, como revisão do lugar da cultura na sociedade brasileira, inserção no mercado e transformação das sensibilidades numa ambigüidade crítica: ao invés do mero recuo em função da transparência da mensagem (o nacional-popular), a recolocação de seus termos no quadro maior das novas estruturas de mercado. ${ }^{6}$ Nas universidades lia-se Marx, Lênin, Mao, Lukács e Marcuse. Nas livrarias, em sua primeira edição em português, surgia $O$ capital, publicado audaciosamente na íntegra pela Revista Civilização Brasileira, então o maior veículo aglutinador da intelectualidade de esquerda e onde colaboravam nomes como Ferreira Gullar, Paulo Francis, Fernando Henrique Cardoso, Leandro Konder e Nelson Werneck Sodré. Na literatura o grupo de vanguarda Poema-Processo realiza o "poema coletivo", espécie de happening de protesto onde vários livros são queimados e picotados; surge o "poema comestível”. ${ }^{7}$ Nas artes plásticas, o conceito de participação, em seu duplo juízo, estético e político, é fundamental para compreender, por exemplo, algo como Apocalipopótese, acontecimento de rua coordenado por Hélio Oiticica que comportava simultaneamente a noção poética fenomenológica de participação do espectador e a noção de participação e engajamento político. ${ }^{8}$ Um belo exemplo dessa conjugação ocorreu na intervenção do artista Antonio Manuel, que espalhava pela rua suas Urnas quentes (caixas hermeticamente fechadas contendo em seu interior frases e imagens sobre a violência da ditadura) e pedia aos transeuntes para arrebentá-las a machadadas. Fervilhava o sentido político.

O efeito social mais visível provocado pela natural politização de uma 
juventude de esquerda "numerosa a ponto de formar um bom mercado" $\mathrm{e}$ pelo recrudescimento contínuo da brutalidade policial do regime, especialmente durante o ano de 1968, foi uma seqüência inacreditável de manifestações de protesto, algumas mais pacíficas, outras bastante violentas.

Testar os limites da ação permitida torna-se uma rotina comum aos membros das oposições intelectualizadas: o que se pode escrever em uma coluna de jornal, o que se pode compor e cantar, o que se pode encenar ou ensinar sem atrair represálias pessoais; que grau de repressão enfrentará o protesto público - o panfleto, a assembléia, a passeata, o comício, a manifestação. ${ }^{10}$

Antes mesmo do Maio francês, a morte do secundarista Édson Luís, assassinado pela polícia carioca durante uma pequena passeata, já funcionara como pólvora acesa ao movimento estudantil brasileiro. Quando, naquele momento, 50 mil pessoas acompanharam o enterro do estudante no Rio de Janeiro, pela primeira vez a opinião pública se sensibilizou pela luta da juventude. Uma semana depois, exatamente no dia 2 de abril, essa sensibilidade se fortaleceria quando, durante a missa de sétimo dia de Édson, uma multidão foi encurralada e massacrada pela cavalaria nas escadas da Igreja da Candelária. As agressões, de parte a parte, vão se tornando mais e mais constantes. As agitações estudantis, como um incêndio desvairado, espalham-se por todo o país. Em Fortaleza, o Serviço de Informações dos Estados Unidos é destruído por manifestantes; em Recife cerca de dois mil universitários realizam uma passeata há pouco proibida; em Belém, os estudantes são retirados à força da Universidade; em Natal, pipocam greves em todas as universidades; na Bahia um estudante ferido pela polícia revolta a população, enquanto na capital do país, a Universidade de Brasília, ocupada pelos estudantes, é cercada pela polícia. Dois estudantes são baleados em Goiânia e três em Minas Gerais, onde um policial é ferido gravemente por um paralelepípedo e um carro oficial é incendiado. Em junho, dia 26, no Rio de Janeiro, diversos setores da sociedade civil organizam uma vultuosa demonstração de descontentamento contra a violência do regime, a Passeata dos Cem Mil. ${ }^{11}$ No Paraná, por sua vez, apesar da aparente sonolência de oposição política reinante num Estado então governado por um costista assumido como Paulo Pimentel, o movimento estudantil também escreveu algumas páginas de efetiva militância: pela derrubada do ensino pago, vários alunos da Universidade Federal do Paraná, armados de coquetéis molotov e estilingues, enfrentaram as armas e os cavalos da polícia militar, num saldo geral de seis policiais derrubados a pedradas e cinqüenta estudantes presos. ${ }^{12}$ 


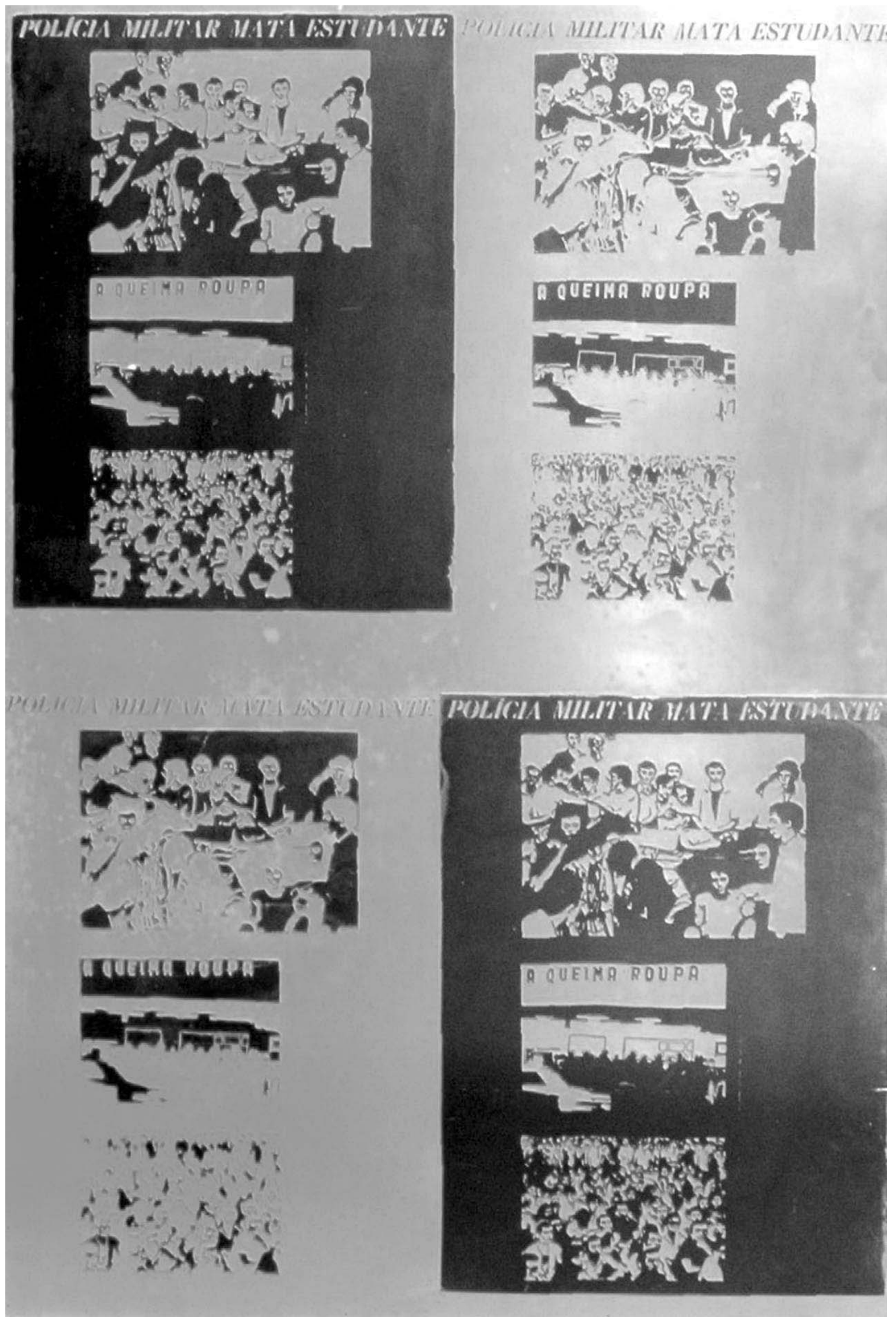

Figura 1. Antonio Manuel. Movimento estudantil 68 A. 1968.

Serigrafia de flan. 122 x $80 \mathrm{~cm}$. 
A resposta do governo Costa e Silva foi desproporcionalmente violenta. Acuado pelos militares radicais em represália à decisão do Congresso em proteger o deputado "Marcito" (Márcio Moreira Alves), o presidente da República leva o projeto do Ato Institucional $n^{\circ} 5$ à votação extraordinária. Com vinte e dois votos a um, o Ato passou a vigorar, previsto inicialmente para durar apenas oito ou noves meses, mas com vigência efetiva de mais de uma década. Durante os dez anos seguintes, seis senadores, 110 deputados federais e 161 estaduais, 22 prefeitos e 22 vereadores foram cassados, num universo de mais de mil e seiscentos cidadãos punidos. No campo da produção cultural, a ação da censura foi igualmente nefasta: 500 filmes, 450 peças de teatro, 200 livros, 100 revistas, 500 letras de música, dezenas de programas de rádio, uma dúzia de capítulos e sinopses de telenovela - todos parcial ou integralmente vetados. ${ }^{13} \mathrm{O}$ movimento estudantil, ao menos em seu perfil utópico de revolução coletiva mais ou menos organizada, foi completamente desarticulado. O atônito silêncio inicial, portanto, prevalecia.

Por outro lado, se a muda receptividade do Salão Paranaense de 1968 já nadava nas águas turvas desse novo e sombrio panorama, algumas das obras nele expostas ainda guardavam as marcas agitadas do momento anterior. Curiosamente, no dia 11 de dezembro, quando o jornal paranaense Gazeta do Povo divulgava, como de costume, em profilática nota os resultados das premiações no Salão daquele ano, um conjunto de três obras igualmente premiadas era, por descuido talvez, simplesmente omitido. ${ }^{14}$ Os artistas laureados tiveram seus nomes publicados, e aos primeiros colocados de cada categoria (pintura, escultura, desenho, gravura) publicavam-se também os títulos de suas obras. Tudo rapidamente, em poucas palavras, de modo bem sintético, refletindo quem sabe, naqueles poucos centímetros quadrados de papel jornal, o pequeno espaço que uma exposição de artes plásticas ocupava na vida pública dos leitores, ou ainda, o que é mais provável, a pequena atenção que a Gazeta dispensava às artes visuais. ${ }^{15}$

Ordenadas alfabeticamente em $A, B$ e $C$, a série de três obras premiadas no Salão e omitidas na Gazeta do Povo intitulava-se, de maneira sugestiva, Movimento estudantil 68 (Figura 1) e pertencia a Antonio Manuel ${ }^{16}$ - o mesmo autor da violenta proposta das Urnas quentes, conhecido artista radicado no Rio de Janeiro, a cidade dos mais veementes confrontos do movimento estudantil e da mais intensa oposição artística ao regime, ao menos nas artes plásticas. ${ }^{17}$

Combativo, Antonio Manuel pertence a uma geração de artistas que assumiu a destruição da interioridade da obra ao mesmo tempo em que a utili- 
zou como veículo de provocação política. ${ }^{18}$ Com ele, artistas distintos como Artur Barrio, Carlos Zílio e Cildo Meireles tinham em comum - sem no entanto formarem um conjunto homogêneo - o fato de assumirem e incorporarem sem pudores essas contradições, de menosprezarem qualquer forma de engajamento didatizante e de combaterem tanto o elitismo institucional da cultura quanto a repressão do sistema político. Se de um lado a denúncia do imobilismo tanto estético quanto político fez desses homens, sim, artistas politizados, de outro, o experimentalismo poético e o comprometimento constante com questões de linguagem, fez deles, sobretudo, artistas.

Sob o viés do engajamento político, o caso de Antonio Manuel por esses tempos, no Brasil, é tão peculiar que representa "um dos poucos exercícios desse tipo bem-sucedidos" ${ }^{19}$ - e é nessa perspectiva que surge a série Movimento estudantil 68, conjunto de obras que por sua vez faz parte de um tema mais amplo do artista - Eis o saldo — em que ele lida com imagens da movimentação dos estudantes contra a ditadura.

Consagrada no Salão Paranaense de 1968, essa série deve ter causado algum impacto nos visitantes do evento. Sua literalidade temática, ao primeiro contato, é tão evidente, e tão agressiva, que dificilmente alguém duvidaria de sua criticidade, ainda mais em momento tão delicado quanto aquele de recentíssima divulgação do AI-5.

\section{“Movimento ESTUdANTIL” NO SALÃo DE 1968}

Como em qualquer manifestação artística, Movimento estudantil guarda, na soma de seus limites formais e sócio-culturais, as possibilidades de sua própria interpretação. Num primeiro contato, uma série de associações básicas emerge de pronto. Uma mesma frase interrompida e desmembrada em duas partes aparece, insistentemente, repetida quatro vezes pela superfície da obra, o que, de certa forma, nos impõe uma leitura inicial:

\section{POLICIAL MILITAR MATA ESTUDANTE}

\section{A QUEIMA ROUPA [sic]}

A provável apelação informativa de cadeias associativas desse tipo reforça o sabor de denúncia contido na mensagem. A ação violenta prevista em "mata a queima roupa" reforça a idéia de morte brutal ou assassinato, enquanto o "estudante" (morto) representa, aqui, uma parcela "organizada" e "resis- 
tente" da sociedade civil, vítima dos desmandos arbitrários de um poder público repressivo indicado em sua ponta de contato mais evidente pela noção de "policial militar" (que mata, à queima-roupa, estudantes).

Como sabemos, as palavras, quando agregadas à extensão de obras visuais, não implicam necessariamente hierarquias de significados, e muito menos ordens preestabelecidas de leitura. Antes, conforme nos mostram diversos exemplos na história da arte moderna, implicam, isso sim, uma certa alteração expressiva, uma renovação das relações verbo-visuais. O jogo de transliteração não é fechado, direto ou inequívoco e se dá, basicamente, de duas maneiras: através da incorporação plástica dos aspectos visuais das letras e palavras ao conjunto da obra - o que implica uma espécie de acentuação de sua realidade bidimensional e planar — e através dos eventuais cruzamentos dos conteúdos lingüísticos com os imagéticos - que por sua vez supõem novos meandros de interpretação.

Se por um lado, consideradas num plano abstrato, as frases impressas em Movimento estudantil nos falam somente sobre o ato político da denúncia e

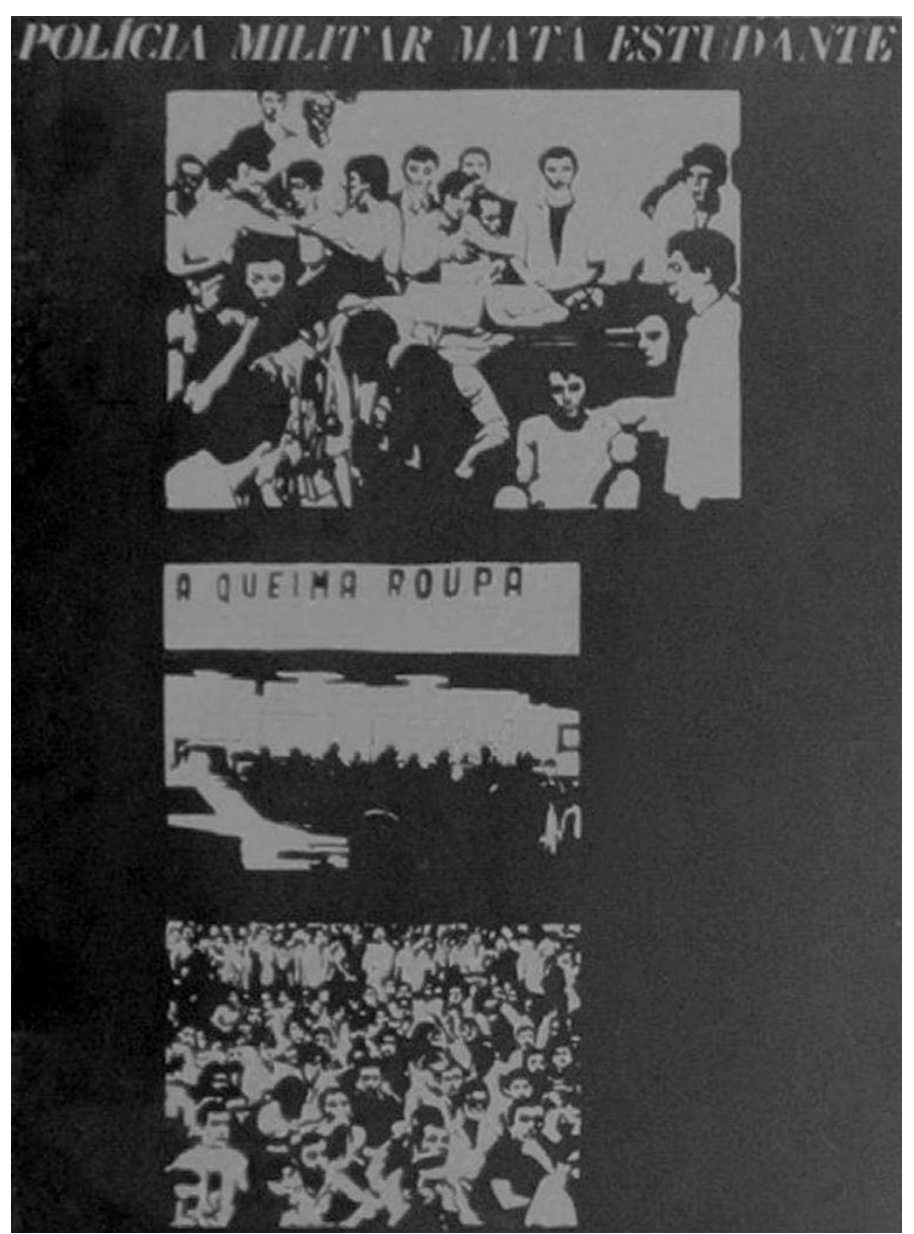

Figura 2. Detalhe. nada sobre a dimensão estética da obra, por outro elas sugerem, enquanto conteúdo verbal, uma das possíveis e imediatas interpretações narrativas das imagens apresentadas. Enquanto mera figuração, por exemplo, as cenas representadas na obra possuem conteúdos específicos que só podem ser descritos com certa precisão a partir da associação temática tanto com as frases apresentadas quanto com o título. Nesse nível de interpretação, o estrato cultural é bastante amplo e genérico, exigindo pouco, portanto, para sua decodificação. A taxa de redundância mais elevada, um razoável grau de naturalismo das representações e 
o apoio mais geral das palavras ajudam a prever uma descrição razoavelmente primária da obra como um todo.

Isoladas em seus mundos particulares e em suas histórias de luta, cada micro-cena, cada pequena caixa de imagens de Movimento estudantil é um testemunho das aflições e utopias de uma sociedade jovem, esclarecida e militante. Em cada ambiente, a multidão é, ao mesmo tempo, o pretexto e o cerne, a potência do coletivo, o resíduo positivo do homem como ser social, mas é também uma acepção plástica, confusa e curiosamente ordenada em cada contorno retangular, é a composição dos contrastes, a dissimulação da mensagem, a ascendência do gesto poético. A massa, de formas e cores, de homens e dores, sobrepõe-se todo o tempo. Não fosse a veemência afirmativa das palavras, sua rigorosa imposição de prumo, a multidão provavelmente desapareceria numa série de articulações frenéticas entre vermelhos e pretos - numa série de agitações formais confinadas e rigorosamente articuladas pela geometria dos retângulos, pela vontade de divisar a tragédia da reflexão, e, talvez, da futura ação. A cada ambiente, uma nova definição, uma sugestão não-linear de leitura. Três cenários distintos, verticalizados uns sobre os outros, repetem-se pela obra, quatro vezes ao todo, invertendo-se em negativos e positivos, resultando em quatro painéis rubro-negros (Figura 2). Entre as pequenas cenas, a primeira e maior é a de mais apelo, é a razão da denúncia, a atrocidade em si, a morte pura e simples (Figura 3).

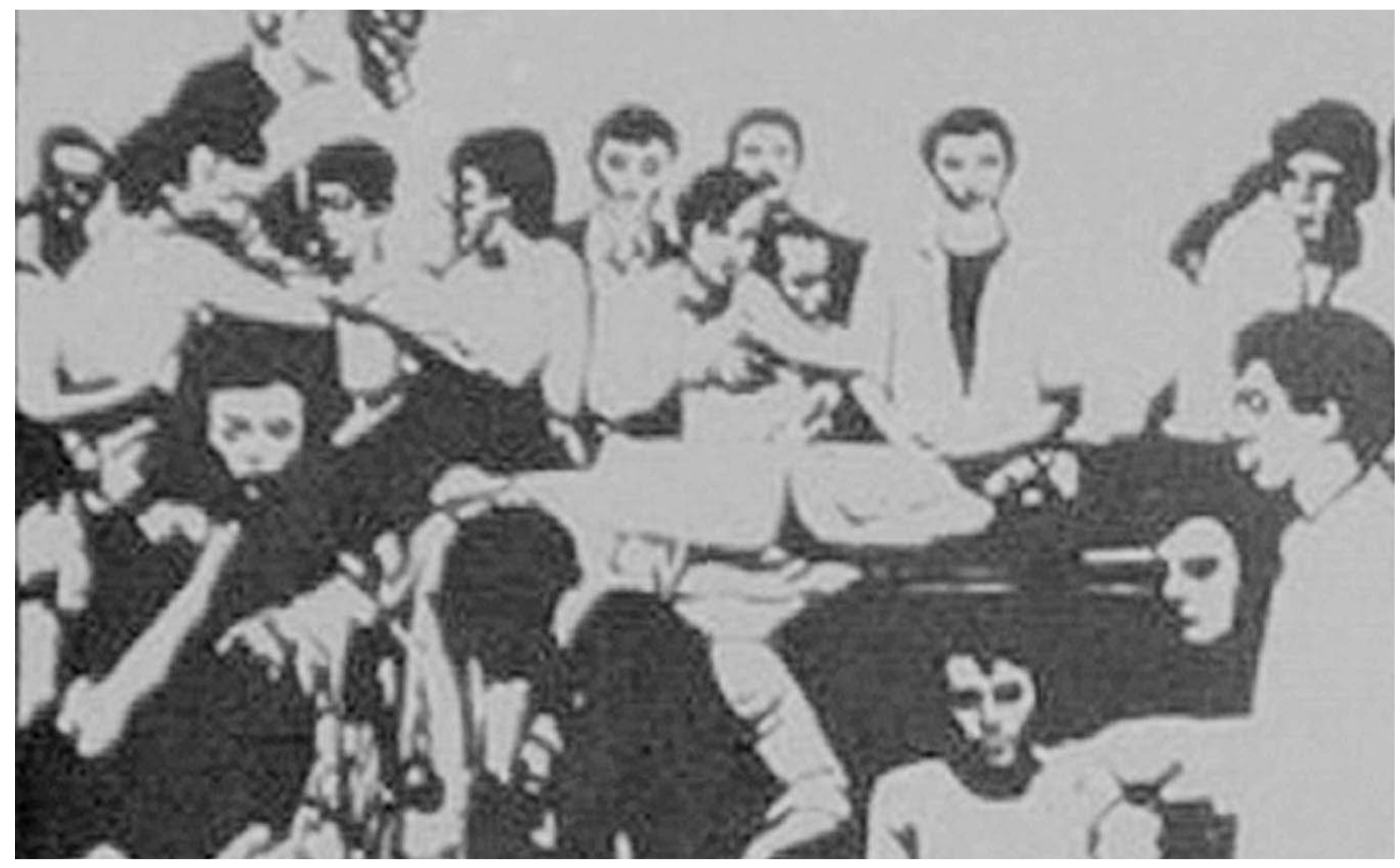

Figura 3. Detalhe. 
O corpo, que jaz inerte, traz como os outros, eretos, que o rodeiam, a marca maior da indefinição e a da impessoalidade. Quando se acha, na mancha ou no traço, um rosto ou um braço, se vê igualmente que tal pormenor é tão inútil quanto sua discriminação. Já não importa quem seja o estudante baleado, quem sejam aqueles que o velam e tampouco os que o lamentam, logo abaixo. Se um estudante está morto, a denúncia supõe e demonstra que algum outro não está. E diante de tão absurdo funeral, as expressões pessoais arrefecem e se entregam à crua exposição dos fatos. A ordem, a essa altura, é necessária à eventual arregimentação da massa social. E elas surgem, a ordem, a massa, integradas em uníssono, num pequeno espaço da obra, dois quadros abaixo do espaço da morte. No limite inferior de cada painel, aplaca-se a fera; senta-se, ouve-se, e talvez se discuta (Figura 4). A massa, de formas, é caótica, mas quase homogênea, compacta, como a massa humana, inerte, resolvendo a história. Incontáveis pessoas, estudantes, fixam olhares num mesmo destino, num flagrante de obediência, de contenção absoluta, aptos no entanto a agir, com todos os vigores e as utopias da juventude. E logo acima deles, como uma lembrança, vem a ligação e ao mesmo passo a separação com o símbolo do risco máximo, o assassinato autorizado. Entre a esperança, a organização e o projeto utópico da quadra inferior, e o limite final da aventura estudantil da quadra superior, surge uma quadra indefinida, um espaço de possibilidades, um esquema formal que é quase pura plasticidade, sem conteúdos determinados.

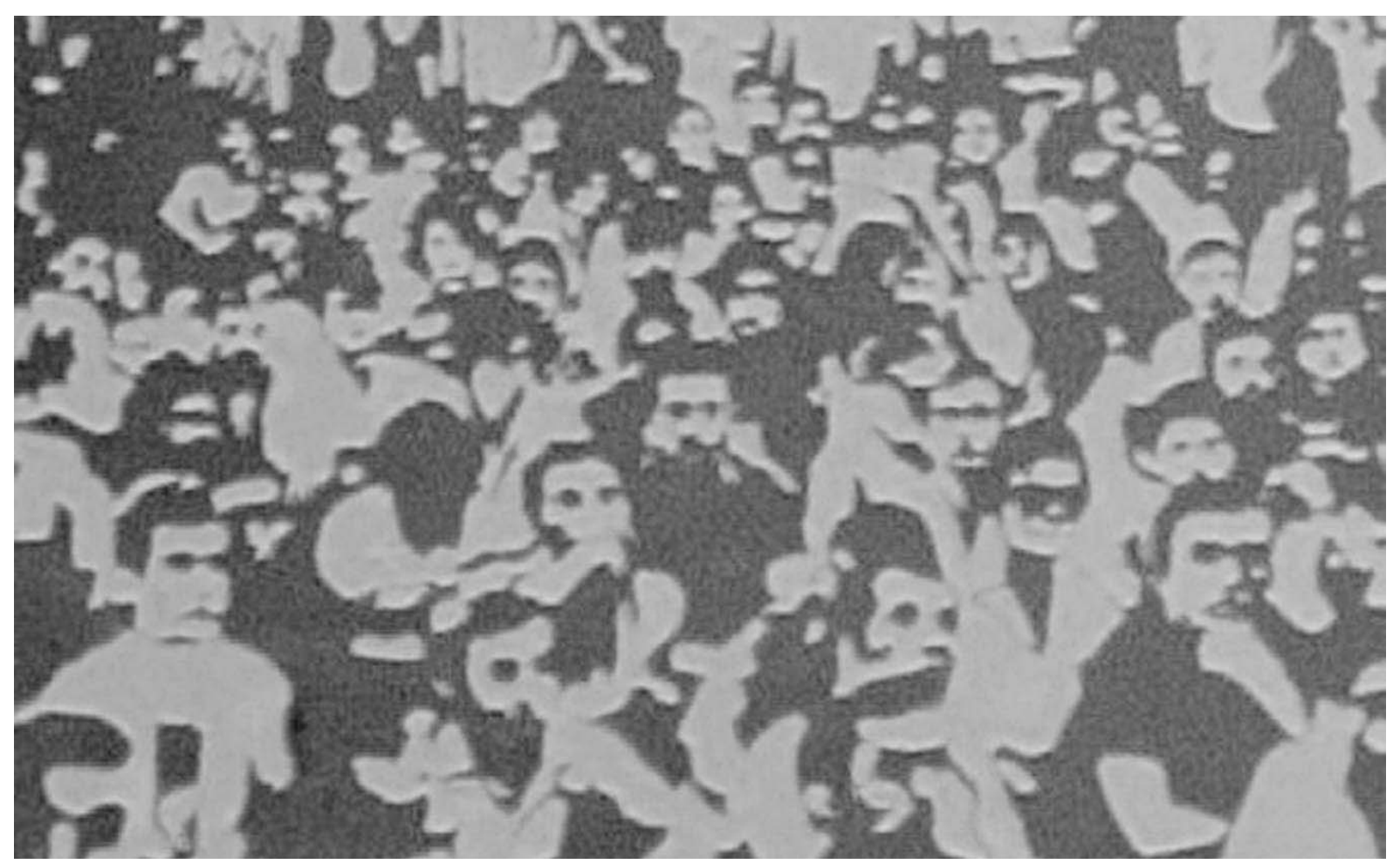

Figura 4. Detalhe. 
Como hímen das concretudes sociais, a realidade da obra se impõe, pois a arte, afinal, não é um lugar de definições, nem um jogo de bom senso, de narrativas lógicas bem resolvidas. Entre a frase "a queima roupa" e uma mancha que é somente puro contraste, há apenas um suave perfil horizontal mais uma vez — da multidão, que se consome, amorfa, na única grande mancha sangrada e sem moldura da obra, na única massa que, realmente indefinida, ao ser arte, é também a descrição do coletivo.

Entretanto, se de um lado, o olhar crítico lançado à obra constrói a base primária de sua apreensão e é essencial à sua inteligibilidade, de outro existem certas camadas de sentido que simplesmente não se desvelam desse modo. Negligenciar esse dado é esperar que a obra, sozinha, nos revele alguns segredos que de qualquer forma não lhe pertencem, pois que a antecedem e são feitos de outra matéria; é confiar, ingenuamente, que o olho nos dê respostas que não lhe competem; é tonificar o mito da arte ontologicamente paralela à história. A simples presença de Movimento estudantil, como obra premiada, naquele Salão Paranaense de 1968, já é razoavelmente elucidativa, e pode servir como exemplo do que digo. Não que a mera reconstrução mental dessa presença me baste para alcançar certas sínteses interpretativas que venho buscando, mas sem a consideração dessa circulação empírica da obra, certas conclusões me seriam muito mais custosas quando não mesmo inviáveis.

Se na confrontação direta com Movimento estudantil consegue-se deduzir uma considerável série de cruzamentos analíticos variáveis conforme a situação do observador, existem certas informações marginais - a meu ver, indispensáveis à pesquisa - que não podem ser assim apreendidas. Dentre elas, destaco algumas, cada qual ligada à outra e, naturalmente, à situação como um todo: a obra enquanto produção material específica; a obra enquanto componente da produção maior do artista e de sua biografia; e a obra enquanto centro e álibi de um circuito cultural concreto e, conseqüentemente, enquanto efetivo agregado de valores simbólicos e econômicos. Em poucas palavras: a produção, o produtor e o lugar da obra no sistema.

Movimento estudantil, por exemplo, com sua superfície muito lisa e um pouco reluzente, seu suporte de madeira, sua fatura exata e a reprodução quadruplicada de algumas mesmas cenas aparentemente fotográficas, denuncia em partes seu processo produtivo: é uma serigrafia, conhecido processo de gravura criado no século XX e freqüentemente utilizado durante os anos 60 por artistas de toda parte..$^{20} \mathrm{~A}$ impessoalidade do processo em si, se no geral re-adapta à mão do artista ao re-adaptar seus elogios, no caso específico dessa obra, surge tão conteúdo quanto as indecifráveis personalidades das multi- 
dões ali representadas. A técnica, nesse caso, e como quase sempre, é causa e efeito do trabalho, é eleita por uma necessidade ao mesmo tempo em que se lhe impõe como limite. Todavia isso é apenas um início de assunto. Lançando hipóteses, creio que coube uma pequena dúvida ao visitante do Salão daquele ano se, ao chegar à obra, dobrou-se um pouco como de costume para informar-se sobre ela através das inevitáveis etiquetas laterais de identificação. ${ }^{21}$ Além de informações elementares sobre autoria e título, Movimento estudantil estaria ali sendo apresentada, do ponto de vista técnico, como uma enigmática "serigrafia de flan".

Se de um lado, como se disse, a serigrafia é um dos mais conhecidos e utilizados processos de impressão, de outro, o uso de um flan - uma peça de oficina gráfica, descartável e utilizada como matriz das superfícies cilíndricas em impressoras rotativas dos jornais diários, posteriormente substituída pelo off-set - como matriz de gravura de arte é algo bastante incomum. Esse gesto, além de original enquanto possível expressão plástica, viria a se tornar, nas mãos de Antonio Manuel, um ato de guerrilha cultural. O flan seria, na poética desse artista, reutilizado enquanto processo produtivo, surgindo como matriz de sua própria serigrafia. Matriz invisível, entretanto; que não se apresenta, que não se denuncia na obra e sim na etiqueta que a identifica e nomeia. Nesse registro, a respiração das cenas em Movimento estudantil altera seu ritmo, muda seu sabor, comporta novos contornos. A contradição é inelutável, pois aquelas imagens — descobrimos — ao serem "figuras em segundo grau", ${ }^{22}$ são tão ficcionais quanto documentais. ${ }^{23}$

Como foram diversas as baixas entre a juventude militante, o estudante morto da serigrafia poderia ser qualquer um, ser simplesmente uma lembrança geral, apenas a idéia-tipo de uma situação-limite plasmada pela imaginação do artista. Mas não é. Aquele estudante, de fato, é a ocorrência da morte. Não sabemos de quem, mas sabemos que logo ganharia as manchetes de algum jornal diário carioca. Porém, vale lembrar que, na obra, o discurso jornalístico com suas letras garrafais e suas fotos apelativas, com sua precisão informativa e com seu forte cheiro de documentação histórica, se subverte. A diluição e o embaçado das representações, a repetição excessiva das mesmas cenas, as pequenas interferências da mão do artista, a inversão em negativo de dois painéis e a permanente incerteza da narrativa, nada disso colabora com a limpidez de sentidos, com a comunicação imediata e alargada, características freqüentes de uma grande imprensa ainda não completamente violada pela censura prévia.

Nas madrugadas de 1968, Antonio Manuel atuava incessantemente. 
Continuei a trabalhar com o jornal, aproveitando o material do dia-a-dia, freqüentando as oficinas do Jornal do Brasil, Correio da Manhã, O Globo e o Paiz, de madrugada, às duas ou três horas, para selecionar os flans, pois eles são considerado material de sucata, e corria o risco de perdê-los, como perdi alguns. $\mathrm{O}$ flan é essa matriz do jornal que tem seus altos e baixos-relevos necessários à impressão. Mas o flan é um material muito bonito e quase invisível, e assim tinha de trabalhar sobre determinados enquadramentos de luz. Tinha que jogar a luz em diagonal, ou de frente, para enxergar o que estava registrado nele. Alguns são inéditos, porque não se podia mostrá-los naquele tempo, e são quase todos relativos à idéia da violência de rua. ${ }^{24}$

Do ineditismo de alguns flans brotam mais algumas possibilidades de interpretação: se já sei que as imagens de Movimento estudantil são coletadas e re-trabalhadas a partir de matrizes de grandes jornais cariocas, via de regra de suas manchetes de capa, conforme nos revela Frederico Morais, ${ }^{25}$ de outro modo já não é certo que essas primeiras-páginas chegaram efetivamente a circular pelas bancas do país. Ou seja: se a manchete específica de Movimento estudantil foi realmente publicada, cresce a possibilidade de que o visitante do Salão de 1968, ao reconhecê-la na obra, desconfie de sua fonte documental. Mas, se aquela manchete foi vetada, seja pela censura interna do órgão de imprensa, seja pela censura externa da força policial, e conseqüentemente não ganhou as capas de algum jornal carioca, a transgressão do gesto do artista ganha então contornos de subversão política, pois corresponderia à divulgação pública de uma mensagem recentemente proibida pela lógica coercitiva do regime. ${ }^{26}$

$\mathrm{O}$ apelo à realidade, o uso da iconicidade, da figuração, a temática agressiva, o mergulho nas especificidades dos problemas brasileiros, a reprodutibilidade da serigrafia, a iconografia de massa, a reapropriação de imagens públicas, os ruídos na comunicação e o processo técnico elaborador enquanto método de referência à censura, todo esse caldo de dados, tudo isso junto marca Movimento estudantil como produto de seu tempo, de fins dos anos 60, talvez especificamente de 1968. Ainda guardam-se esperanças nas forças do coletivo, no protesto de rua; ainda não se encarou o silêncio das ações armadas. E mesmo na trajetória pessoal de Antonio Manuel, a obra ainda é formalização estética radicalmente diferente de sua produção ulterior. Mesmo que as Urnas quentes, também de 1968, guardassem em seu interior excertos desses flans, Movimento estudantil ainda não sugere, em si, essa participação. Ainda é matéria posta à contemplação, mesmo que indignada, mas ainda é. Se as Urnas quentes de Antonio Manuel ou os Parangolés de Oiticica já operavam no regis- 
tro do acontecimento, da ação performática, e não mais no do retiniano (como diria Duchamp), não se pode dizer o mesmo de Movimento estudantil. ${ }^{27}$

Nos anos seguintes, com a confirmação de toda a potência da arte conceitual, bem como com o recrudescimento da brutalidade do regime e com as benesses classe-média do "milagre brasileiro", o contexto é outro, as produções culturais também. O happening, no sentido mais amplo de "acontecimento", embora nem sempre compreendido, torna-se a síntese plástica da nova expressividade. A arte como processo é levada às últimas conseqüências, aos limites da vanguarda.

Por ora, contudo, convém ainda destacar mais um aspecto que relaciona Movimento estudantil ao seu tempo.

\section{DA VANGUARDA NO SALÃO À IRONIA DO JÚRI}

Note-se que os flans que deram origem ao radicalismo de Urnas quentes são os mesmos flans comportadamente premiados no Salão Paranaense de 1968; e que o artista que, numa praça pública, cobra dos passantes uma ação violenta e lhes oferece machados em vez de olhos, é o mesmo que envia sua série de combativas obras ao julgamento oficial de um júri de seleção e que dispõe, portanto, suas obras à mercê da lógica institucional do mundo da arte. Por qual razão, afinal, um artista que, sob a égide das operações das vanguardas brasileiras - e que portanto trabalha num registro de crítica não só ao regime militar mas sobretudo às próprias instituições artísticas —, acaba por sujeitar suas obras ao julgamento de um salão de arte? Esse aspecto, aliás, se é realmente contraditório, não é entretanto de todo incompreensível.

Durante os anos 60, uma parcela significativa das artes plásticas brasileiras re-adaptava certos expedientes antiinstitucionais das vanguardas históricas às necessidades dos novos contextos. Ao longo desses anos, à medida que o meio artístico no Brasil reforçava suas instituições e valores, paralelamente alguns artistas fizeram dos esforços de combate à institucionalização e à oficialidade de uma cultura conservadora uma prática constante. Daí decorre o fato de a arte de vanguarda ter tanto ido para as "ruas" - ou seja, para fora dos museus e das galerias, como por exemplo em Domingos da Criação ou Do Corpo à Terra, ambos organizados por Frederico Morais - quanto combatido "de dentro" as instituições artísticas - como por exemplo o Happening da Crítica, de Leirner, ou o Manifesto, de Artur Barrio —, para ficar nos exemplos mais conhecidos. No entanto, é preciso destacar, em detrimento de toda 
potência do gesto vanguardista, que esses mesmos espaços institucionais combatidos serviam, em última instância, como meios indispensáveis de consagração e subsistência, mesmo ao mais rebelde dos artistas. Os Salões, as Bienais, os acervos consagrados, as palavras do crítico e o mercado de arte instituições por princípio questionadas pela vanguarda crítica - ainda resistiam não somente como a única fonte possível de reconhecimento e ganhos materiais, mas, principalmente, resistiam como a esfera legítima de reprodução de certos valores comuns ao entendimento da arte moderna, esfera essa em que, de qualquer forma, os artistas ainda circulavam entre pares, julgavam-se entre iniciados e se resguardavam de certos desmandos da sociedade em geral.

E é nesse sentido que convém ter em conta tanto a análise da obra quanto a análise das instituições culturais: tanto uma quanto outra, dialeticamente, influenciam-se de modo recíproco, influenciam as transformações perceptivas e culturais de certas formações sociais, ao mesmo tempo em que são também influenciadas por elas. Algumas instituições culturais, por exemplo, como certos salões de arte, se de um lado agregam valores e sentidos às obras que veiculam, de outro se alteram e se deformam, da mesma maneira, pelo legado dessas mesmas obras.

A esse respeito não é exceção o Salão Paranaense de 1968, o último organizado por Ennio Marques Ferreira, diretor do Departamento de Cultura da Secretaria de Estado da Cultura do Paraná desde 1961. A presença, durante os últimos cinco ou seis anos, de artistas premiados como Anna Bella Geiger (1963), Antonio Dias (1963), Rubens Gerchman (1964), Frederico Nasser (1965-1967) e o próprio Antonio Manuel (1966-1968), entre outros, e de críticos como Mário Barata (1963), Walter Zanini (1964), Geraldo Ferraz (1966), José Roberto Teixeira Leite (1966) e Clarival do Prado Valladares (1967), sem dúvida corroborava a seriedade do certame e, o que é mais importante, sua vocação à contemporaneidade. A simples presença desses nomes, tão caros ao campo artístico dos grandes centros brasileiros, injetava doses de certo reconhecimento à grife "Salão Paranaense", ao mesmo tempo em que lhe conferia, enquanto instituição abalizada, a devida autoridade de julgar e, portanto, de consagrar. Naquele ano de 1968, compunham o júri de seleção o próprio Ennio Marques, que substituía, na qualidade de suplente, a Pietro Maria Bardi, além dos artistas plásticos Loio-Pérsio e Ivan Serpa, este último ex-professor de Antonio Manuel no Rio de Janeiro. ${ }^{28}$

Quando pensamos no processo seletivo de um salão de arte, é importante não perder de vista, portanto, que se de um lado uma obra se torna inequi- 
vocamente "de arte" graças ao "batismo" das escolhas do júri, de outro, o próprio júri de seleção, em seu projeto de legitimação institucional das obras, assina com suas escolhas uma espécie de contrato de cumplicidade com elas. Não temos, é claro, como saber quais foram exatamente as eventuais leituras que Loio-Pérsio, Ivan Serpa e Ennio Marques fizeram de Movimento estudantil à época daquele salão, nos idos de 1968, mas fora o fato de a terem escolhido e premiado, há ainda um último dado curioso que vale a pena mencionar.

Como ocorreria até 1976, as premiações nesse ano foram majoritariamente concedidas pelo governo do estado do Paraná, através de diversos de seus órgãos. De um total de NCr\$16.100,00 em dinheiro, mais da metade (NCr\$ 8.500,00) veio dos cofres públicos estaduais. ${ }^{29}$ Curiosamente, talvez por alguma lúdica e inteligente sutileza da comissão julgadora - que é quem decide qual prêmio de qual instituição vai para qual obra - o único prêmio federal coube justamente à obra de Antonio Manuel. A própria premiação, aqui, não deixa de conter em si a evidência de uma pequena blague, quando, ao garantir NCr\$1.000,00 ao bolso do artista, Movimento estudantil se vê ironicamente laureada com o "prêmio Universidade Federal do Paraná" - em alusão ao maior palco da movimentação estudantil paranaense em 1968.

\section{NOTAS}

${ }^{1}$ Pesquisa realizada com apoio financeiro da Capes.

${ }^{2}$ Doutorando em História pela Universidade Federal do Paraná e bolsista pela Capes. Autor, entre outros, de "História e imagem artística: por uma abordagem tríplice" publicado no dossiê "História e Imagem" da Revista Estudos Históricos, n.34, 2004; de "Poéticas políticas: as artes plásticas entre o golpe de 64 e o AI-5", em História: Questões e Debates, n.40, 2005; e de "A autonomia social da arte no caso brasileiro", ArtCultura, n.11, 2005 (no prelo).

${ }^{3}$ Dados retirados da seguinte coletânea de documentos: JUSTINO, M. J. (Org) 50 anos de Salão Paranaense. Curitiba: Clichepar, 1995, p.270.

${ }^{4}$ MARCONI, P. A censura política na imprensa brasileira: 1968-1978. São Paulo: Global, 1980.

${ }^{5}$ VENTURA, Z. 1968: o ano que não terminou. Rio de Janeiro: Nova Fronteira, 1988, p.291-2.

${ }^{6}$ FAVARETTO, C. Tropicália: alegoria, alegria. São Paulo: Ateliê Editorial, 1996; NAPOLITANO, M. A república das bananas: o tropicalismo no panorama da MPB. In: Seguindo a canção: engajamento político e indústria cultural na MPB (1959-1969). São Paulo: Annablume, Fapesp, 2001, p.233-86.

${ }^{7}$ MORAIS, F. Cronologia das artes plásticas no Rio de Janeiro: 1816-1994. Rio de Janeiro: 
Topbooks, 1995, p.305; HOLLANDA, H. B. Impressões de viagem. São Paulo: Brasiliense, 1980.

${ }^{8}$ Hélio Oiticica, por exemplo, alertava sobre a premência dessa noção, dizendo que "o que [Ferreira] Gullar chama de participação é no fundo essa necessidade de uma participação total do poeta, do artista, do intelectual em geral, nos acontecimentos e nos problemas do mundo ... Desde as proposições 'lúdicas' às do 'ato', desde as proposições semânticas da 'palavra pura' às da 'palavra no objeto', ou às de obras 'narrativas' e às de protesto político ou social, o que se procura é um modo objetivo de participação" OITICICA, H. Texto publicado no catálogo da exposição Nova objetividade brasileira, Museu de Arte Moderna, Rio de Janeiro, 1967.

${ }^{9}$ SCHWARZ, R. O pai de família. Rio de Janeiro: Paz e Terra, 1978, p.62.

${ }^{10}$ TAVARES, M. H. e WEIS, L. Carro zero e pau-de-arara: o cotidiano da oposição de classe média ao regime militar. In: SCHWARCZ, L. M. (Org) História da vida privada no Brasil: contrastes da intimidade contemporânea. São Paulo: Companhia das Letras, 1998, p.330.

${ }^{11}$ VENTURA, Z., op. cit., p.109-64; MARTINS FILHO, J. R. Movimento estudantil e ditadura militar: 1964-1968. Campinas: Papirus, 1987.

${ }^{12}$ HAGEMEYER, R. R. 1968: ano da derrubada do ensino pago no Paraná. In: MARTINS $\mathrm{F}^{o}$, J. R. (Org) 1968 faz 30 anos. Campinas: Mercado das Letras, São Paulo: Fapesp, São Carlos: Ed. UFSCar, 1998, p.115-6.

${ }^{13}$ VENTURA, Z., op. cit., p.263-86.

${ }^{14}$ Gazeta do Povo, Curitiba, 11 dez. 1968.

${ }^{15}$ Ao contrário de jornais como o Estado do Paraná e principalmente o Diário do Paraná, a Gazeta do Povo publicou, durante os anos 60, notas muito esporádicas sobre artes visuais. De qualquer forma, a década de 1970 seria muito mais pródiga a esse respeito, sobretudo pela incansável atuação da crítica de arte Adalice Araújo que, a partir de 1968, assinaria semanalmente a coluna de artes plásticas do Diário do Paraná, passando, ao final dos anos 70, a escrever para a Gazeta do Povo. A essa época, Aramis Millarch e Aurélio Benitez, ambos jornalistas, também escreviam regularmente sobre artes plásticas.

${ }^{16}$ Manuel, Antonio da Silva Oliveira (Avelãs de Caminha, Portugal, 1947). Artista plástico. Chega ao Brasil em 1953, fixando-se no Rio de Janeiro. Em meados da década de 1960 estuda na Escolinha de Arte do Brasil, com Augusto Rodrigues, e no ateliê de Ivan Serpa. É aluno ouvinte da Escola de Belas Artes. Em 1967 realiza sua primeira exposição individual, na Galeria Goeldi. No ano seguinte, no evento Apocalipopótese, organizado por Hélio Oiticica, cria em praça pública as Urnas Quentes, oferecendo machados aos transeuntes e lhes pedindo que destruam algumas caixas de madeira hermeticamente fechadas que continham em seu interior imagens e textos jornalísticos sobre conflitos sociais causados pela repressão militar. Nesse mesmo ano, embora selecionado para representar o Brasil na Bie- 
nal de Paris, acaba não indo à França, pois a exposição prévia brasileira, ainda em solo nacional, é fechada pelo exército. É premiado, em 1969, no Salão da Bússola, com uma obra alusiva à situação política da América Latina. Em 1970, inscreve a obra O corpo é a obra no $19^{\circ}$ Salão Nacional de Arte Moderna, sendo recusado pelo júri. Ainda assim, impõe sua obra ao público, descendo nu as escadas do MAM-RJ. Três anos mais tarde, enquanto prepara uma individual sua no MAM-RJ, a exposição, por medo da censura oficial, acaba sendo censurada internamente, pelo próprio pessoal do museu. Antonio Manuel recolhe o material e o "expõe" em seis páginas impressas e publicadas em O Jornal: era a exposição De zero às 24 horas nas bancas de jornais. Nesse mesmo ano, realiza os filmes Loucura e Cultura, premiado no $3^{\text {o }}$ Festival de Curta-Metragem do Jornal do Brasil e Semi-Ótica, que seria premiado como melhor filme socioantropológico na 5 $5^{\mathbf{a}}$ Jornada Brasileira de CurtaMetragem de Salvador, em 1975. Em 1984, ganha bolsa de pesquisa no Primeiro Concurso Ivan Serpa, realizado pela Funarte. Em 1990, Rogério Sganzerla dirige o vídeo Anônimo e Incomum, sobre os trabalhos do artista.

${ }^{17}$ Desde aquela época, e até os dias de hoje, o Salão Paranaense mantém a seguinte política de aquisição de obras para formação de acervo: do conjunto das obras (normalmente três) premiadas de um artista, uma obrigatoriamente fica à disposição da organização do evento, sendo incorporada à coleção do órgão promotor do salão na ocasião. Das três obras de Antonio Manuel premiadas no Salão daquele ano, graças a essa política de aquisição e conservação, uma nos chega até hoje, como parte do acervo do governo do Estado. Essa obra, intitulada Movimento estudantil 68 A e tombada sob o $\mathrm{n}^{-}$70/0082, pertence ao Museu de Arte Contemporânea do Paraná.

${ }^{18}$ BRITO, R. Anônimo e comum [1983]. In: MANUEL, A. [et al.]. Antonio Manuel. Textos de Frederico Morais, Hélio Oiticica, Mário Pedrosa e Ronaldo Brito. Rio de Janeiro: Funarte, 1984 , p.9.

${ }^{19}$ DUARTE, P. S. Anos 60: transformações da arte no Brasil. Rio de Janeiro: Campos Gerais, 1998 , p.69.

${ }^{20}$ Serigrafia: gravura a cores baseada no princípio do estêncil, e que permite, evidentemente, a reprodutibilidade de uma mesma imagem-matriz. Graças, sobretudo, à pop, e à produção de Andy Warhol em especial, a serigrafia ecoava com certa facilidade por esses anos.

${ }^{21}$ Como se sabe, assim como não há espaço para a imparcialidade durante um processo de julgamento, seleção e premiação de produções culturais, também não há neutralidade em qualquer processo de montagem espacial e simbólica de uma exposição. Vários são os fatores extra-estéticos que colaboram na justaposição de novos significados às obras expostas. A disposição de uma obra em relação à outra, em relação à arquitetura do museu ou da galeria e em relação ao corpo do visitante já sugere, por si só, múltiplos percursos de leitura e, conseqüentemente, imposições mais ou menos rígidas de conteúdos, hierarquias e valores. Um dos dispositivos mais comuns de alta interferência significante e mesmo de inversão de sentidos é a etiqueta identificadora das obras, um pequeno adesivo colocado ao lado delas contendo informações fundamentais ao visitante como nome do autor, títu- 
lo da obra, dimensões exatas do trabalho, data de produção e descrição dos materiais utilizados. Via de regra, tais etiquetas não cumprem apenas a função de legendas informativas, mas atuam dubiamente acopladas à identidade da obra, sugando-lhe a linguagem particular justamente ao guiar-lhe os valores estéticos, históricos e econômicos. Através dessas pequenas bússolas simbólicas o mito da autenticidade e da raridade, tão caros à sociedade capitalista, confirma e legitima seu status quo. O nome do artista, em primeiro lugar, é informação basilar: ao crítico, pode ser a caução do valor estético; ao marchand e o seu freguês, a garantia de conversão da aura em valor econômico; ao historiador, a segurança da relevância e da veracidade. O título da obra, por sua vez, suga sua importância de um gesto de vontade do artista, que em muitos casos opta por influenciar na interpretação sempre polissêmica das suas imagens através da imposição de significados lingüísticos. O teor pragmático, por exemplo, do título em Movimento estudantil, se de um lado não contraria o discurso visual da obra, de outro delineia certezas narrativas: a crer no título, as imagens são instantâneos flagrantes de uma conhecida história social.

${ }^{22}$ DUARTE, P. S., op. cit., p.69.

${ }^{23}$ Uma vez que as imagens presentes nesses flans são apropriações de uma série técnica de reprodução que tem seu início numa fotografia, a dimensão semiótica desses produtos pode guardar certa relevância à própria argumentação. Embora eu não tenha aqui interesse em me alongar a respeito das discussões sobre a ontologia da imagem fotográfica, cumpre por ora destacar que compreendo a fotografia tanto como técnica quanto como linguagem. Como técnica, ou seja, como imagem produzida por aparelhos (FLUSSER, V. Ensaio sobre a fotografia: para uma filosofia da técnica. Lisboa: Relógio D’água, 1988, p.33), a fotografia guarda certas relações físico-químicas com seu referente, o que equivale a aceitála, enquanto processo produtivo, como um indice do objeto fotografado. (PEIRCE, Ch. S. Semiótica. São Paulo: Perspectiva, 2000. p.65.) É sob essa perspectiva que o caráter documental de Movimento estudantil se evidencia, pois que indica, de fato, uma conexão física com seu objeto. Sob outro aspecto, entretanto, a fotografia surge como linguagem autônoma, e como tal, como resultado cultural de um duplo processo simbólico, tanto formativo quanto interpretativo. (DUBOIS, Ph. O ato fotográfico e outros ensaios. 2.ed. Campinas: Papirus, 1998, p.25-53.) Ou seja, a fotografia também é resultado, a um só tempo, de certos esquemas conceituais do fotógrafo, bem como das possibilidades interpretativas do observador, o que faz que ela, ao ganhar em 'ficção', liberte-se da falácia da objetividade.

${ }^{24}$ Depoimento de Antonio Manuel em MANUEL, A. [et al.] Antonio Manuel, cit., p.45.

${ }^{25}$ MORAIS, F., op. cit., p.30.

${ }^{26}$ Conforme nos lembra Paolo Marconi, de acordo com os artigos 61, 62 e 63 da Lei de Imprensa instituída em 1967, o Ministério da Justiça poderia apreender, a qualquer momento, e sem mandado judicial, qualquer veículo de imprensa que contivesse "propaganda de guerra" ou que promovesse "incitamento à subversão da ordem política e social ou ofendam a moral pública e os bons costumes' (artigos 61,62 e 63)”. MARCONI, P., op. cit., p.33. 
${ }^{27}$ Para Oiticica, "o flan q era desenho ou gravura matriz / torna-se / elemento-cerne encerrado na caixa / caixa fechada q é aberta a marteladas: pra possuir-se o código poético / tem q violar a integridade do objeto-caixa acabado / ACABAR COM O ACABADO / dentro o flan / é não-gravura / não pôster / não-serigrafia”. OITICICA, H. Urnas quentes de Antonio Manuel, 22 abril de 1973, New York. Se o flan é não-gravura e não-serigrafia, só o é na medida em que se encontra "encerrado na caixa", no calor das urnas. Antes, entretanto, e é esse o caso de Movimento estudantil, o flan "era desenho ou gravura matriz".

${ }^{28}$ De acordo com artigo publicado pelo crítico de arte Walmir Ayalla, previa-se uma comissão julgadora formada "pelo crítico Pietro Maria Bardi, diretor do Museu de Arte de São Paulo, pelo artista Ivan Serpa, professor do Museu de Arte Moderna do Rio de Janeiro, e um terceiro membro escolhido em eleição a ser realizada em Curitiba, podendo nela votar os artistas que tenham sido, anteriormente, aceitos no Salão Paranaense”. AYALA, W. Salão Paranaense, Jornal do Brasil, Rio de Janeiro, 3 dez. 1968.

${ }^{29}$ Através do Teatro Guaíra, da Fundepar, do Museu Paranaense, da Biblioteca Pública do Paraná ou da própria Secretaria de Educação e Cultura. 